\title{
Motherhood and Decision-Making Among Women Living with HIV: A Systematic Review with Qualitative Research Synthesis.
}

\section{Ariadna Huertas-Zurriaga}

Hospital Universitari Germans Trias i Pujol

Patrick Albert Palmieri ( $\triangle$ patrick.palmieri@jbisa.org )

Universidad Norbert Wiener https://orcid.org/0000-0002-0765-0239

Joan E. Edwards

Texas Woman's University

\section{Sandra K. Cesario}

Texas Woman's University

\section{Sergio Alonso-Fernandez}

Hospital Universitari Germans Trias i Pujol

\section{Lidia Pardell-Dominguez}

Universitat Autonoma de Barcelona

\section{Karen A. Dominguez-Cancino}

Universidad Norbert Wiener

Juan M. Leyva-Moral

Universitat Autonoma de Barcelona

\section{Research}

Keywords: AIDS, Decision-making, HIV, Pregnancy, Reproductive health, Women

Posted Date: July 1st, 2020

DOI: https://doi.org/10.21203/rs.3.rs-38708/v1

License: (c) (i) This work is licensed under a Creative Commons Attribution 4.0 International License. Read Full License

Version of Record: A version of this preprint was published at Reproductive Health on July 10th, 2021. See the published version at https://doi.org/10.1186/s12978-021-01197-6. 


\section{Abstract}

Objective: To explain the reproductive decision-making process of women living with HIV according to their experiences.

Design: Systematic review with qualitative research synthesis. Studies were assessed with the Critical Appraisal Skills Programme and the JBI Checklist for Qualitative Research. The protocol was registered with PROSPERO, and the results reported in adherence with the PRISMA statement and the ENTREQ recommendations.

Setting: Studies with qualitative data from member countries of the Organization for Economic Cooperation and Development were selected to maintain consistency in the conditions of women living with HIV, including socioeconomic, human rights, and access to health services.

Participants: Studies published in journals from 1995 to 2019 with qualitative data about reproductive decision-making among women living with HIV were searched in multiple databases, including CINAHL, EMBASE, MEDLINE (through PubMed), Scopus, Social Science Citation Index, Web of Science, Google Scholar, and the Spanish databases Cuidatge, Cuiden Enfispo, and SciELO.

Results: From the 4,198 articles identified and assessed, 18 were included for analysis and synthesis with 1,333 participants from 10 countries. Three meta-categories were constructed from 15 themes that emerged from 45 subthemes to give new meaning to the phenomena of reproductive decision-making for women living with HIV as 1) Shattered identity, 2) Barriers, inequities, and misinformation, and 3) Coping, resiliency, and support.

Key Conclusions: Reproductive decision-making is a complex process with multiple challenges that women living with HIV encounter with knowledge deficiencies and limited social support. Decisions need to be taken judiciously by women living with HIV in collaboration with clinicians within the context of a supportive health system.

Implications for practice: An integrated approach to care with comprehensive multidisciplinary counseling are needed to support women living with HIV as they engage in reproductive decision-making. Clinicians require professional development as well as evidence-based clinical guidelines and educational resources to support person-centered care for these women, and their families.

\section{Plain English Summary}

Women with HIV can become pregnant and deliver a healthy baby due to advances in medicine. Being a mother is an important role that gives meaning to life for most women. For women with HIV thinking about having a baby is difficult because HIV complicates many areas of daily living. When women with HIV try to speak with physicians and nurses about having a baby, they do not feel supported and report feeling stigmatized. This review of the scientific literature summarizes the experiences of women with 
HIV as they considered having a baby. Ten electronic databases were searched for studies published between 1995 and 2019 reporting interviews with women with HIV about becoming pregnant and having a baby. From the 4,198 articles identified, 18 were included for review with 1,333 participants from 10 countries. After abstracting and analyzing the interviews, three themes were developed to summarize the process described by women living with HIV as they considered pregnancy and the possibility of having a baby, including: 1) Shattered identity, 2) Barriers, inequities, and misinformation, and 3) Coping, resiliency, and support. When women with HIV consider having a baby, they need to feel comfortable and safe speaking with physicians and nurses about family planning. They also need much more support from their partner, as well as family and friends. Strategies need to be implemented to improve the family planning process for women with HIV, including education health care providers about speaking to women about pregnancy and having a healthy baby.

\section{Introduction}

Globally there are 37.9 million people living with HIV [31.1 million-43.9 million], more than half are women.[1] In 2018, $82 \%$ of pregnant women living with HIV had access to antiretroviral treatment to prevent mother-to-child transmission, with higher rates in developed countries.[2] The wider treatment coverage with improved adherence among women living with HIV (WLH) has rapidly reduced the AIDSrelated deaths among women.[3] As such, increased access to Highly Active Anti-Retroviral Therapy (HAART) has shifted HIV from an acute illness to a chronic disease[4] in terms of life expectancy, quality of life, and the opportunity for motherhood.[5-7]

Motherhood is an important role that gives meaning to a woman's life; however, decisions about pregnancy and childbearing are often complex as HIV impacts many aspects of daily living.[8] For example, there is increased risk for complications during pregnancy $[5,8]$ including maternal infection and adverse perinatal outcome.[9-11] Consequently, the factors influencing reproductive decision-making are remarkably different for WLH, including the potential for the baby to be HIV infected and the pregnancy impact on health and wellness.[10, 12] Following the introduction of HAART, mother-to-child transmission has been significantly reduced to less than $1 \%$ [13], but the knowledge transfer into clinical practice has been slow.[14]

Researchers have suggested HIV serostatus and/or knowledge about HIV transmission does not significantly influence reproductive decision-making for WLH.[15, 16] Due to the available conception and contraception options, WLH can avoid pregnancy or safely attempt pregnancy with good rates of success.[17] About a third of WLH reported a pregnancy since diagnosis.[9] Prior to HAART cesarean section was the recommended mode for delivery $[18,19]$ but European guidelines began promoting vaginal delivery[20] as maternal viral load was identified as the most significant risk factor for perinatal HIV infection.

\section{Rational for Review}


Despite the increasingly favorable situation for pregnancy with HIV, WLH lack the evidence-based information about reproductive options while managing pressures from family, clinicians, and communities to give up the idea of having children.[16, 21] Since the reproduction intentions of WLH are not well understood, stigmatizing behaviors force them to hide the disease to avoid rejection by their family, partner, and/or social networks.[8] Compliance with social norms, fear of stigma, and expectations for discrimination influence the experiences WLH and their partner.[22]

Misinformation and prejudice continue to be problematic in clinical practice[23] as WLH do not feel supported by their clinicians and report discrimination and stigma in some cases[24]; resulting in fear and anxiety that negatively impacts relationships with their clinics and confidence in the health system.[25] WLH require comprehensive evidence-based care to safely fulfill their decisions about motherhood, whether this involves preventing or safely advancing a pregnancy[10] to have their own family.[26] However, the current state of research involving reproductive decision making and pregnancy for women with HIV/AIDS can be defined as a substantial knowledge gap in the literature[14, 27] Therefore, the purpose of this study was to explain the reproductive decision-making process of women living with HIV according to their lived experiences.

\section{Methods}

Qualitative research synthesis (QRS)[28], or the aggregative approach to synthesis[29], is aligned with the philosophy of pragmatism where "meanings exist as ready-made"[30] to convey "practical usefulness"[31] that informs decisions and practices at the clinical or policy levels.[32] As such, the result of a QRS is more than a simple summary of findings from the literature.[33] For this reason, we completed a QRS with a multinational team approach[34] to interpret data from systematically selected articles to generate new insights and additional knowledge.[35] The research protocol (CRD42018091971) was registered with the International Prospective Register of Systematic Reviews, PROSPERO[36]. The results are reported according to the Preferred Reporting Items for Systematic Reviews and Meta-Analyses, PRISMA, statement[37], and the Enhancing Transparency in Reporting the synthesis of Qualitative research (ENTREQ) recommendations.[38]

\section{Inclusion Criteria}

Studies published in peer-reviewed journals between January 1995 (the year HAART appeared) and December 2018 using qualitative methods to address reproductive decision-making in WLH were included in this study. Only research reported from countries of the Organization for Economic Cooperation and Development (OECD) were selected for inclusion, maintaining consistency in the conditions for WLH. In this regard, OECD countries are more likely to be compliant with international laws, human rights conventions, and evidence-based clinical practice guidelines for HIV/AIDS. [39-42] The publication language was limited to English, French, German, Portuguese, and Spanish as these were the languages available on the research team. Studies were excluded if the population was focused on women less than 18 years or more than 50 years of age, women living in prisons or psychiatric 
institutions, or mixed-method studies or systematic reviews in which qualitative findings could not be separated from the quantitative.

\section{Search Strategy}

Although most of the qualitative research articles for this review were anticipated to be indexed in the MEDLINE database[43], we were interested in locating all research articles related to reproductive decision-making and WLH. As such, the database filters specific to research methods were not used to limit the possibility for bias in article selection.[44] In order to minimize unintended bias in the search strategy, we referenced the available published recommendations for each database, including CINAHL[45], EMBASE [46], MEDLINE[47] and PsycINFO[48]. Keywords were defined by the research team, informed by systematic reviews in related areas, and joined by Boolean operators for the database searches. Keywords were used to avoid problems with the unique thesaurus terms for each database with varied meanings between disciplines.[46, 49] The keywords included: HIV, AIDS, human immunodeficiency virus, acquired immunodeficiency syndrome, women, women living with HIV, childbearing, desire for children, fertility, family planning, pregnancy, reproduction, reproductive behavior, reproductive choice, reproductive health, decisions, decision making, intention, and mother-to-child transmission. An example of the algorithm used for the search (PubMed) is provided in Table 1. 


\begin{tabular}{|l|} 
("Reproductive Health"[Mesh]) AND women living with HIV \\
("Decision Making"[Mesh]) AND "Fertility"[Mesh]) AND "HIV"[Mesh] \\
("Reproductive Behavior"[Mesh]) AND "Fertility"[Mesh]) AND "HIV"[Mesh] \\
("Reproductive Behavior"[Mesh]) AND "Decision Making"[Mesh]) AND "HIV"[Mesh] \\
("Reproductive Behavior"[Mesh]) AND "HIV"[Mesh] \\
("Fertility"[Mesh]) AND "Intention"[Mesh]) AND "HIV"[Mesh] \\
\hline ("Reproduction"[Mesh]) AND "Decision Making"[Mesh]) AND "HIV"[Mesh] \\
\hline ("Decision Making"[Mesh]) AND "Reproductive Health"[Mesh]) AND "HIV"[Mesh] \\
\hline ("Family Planning Services"[Mesh]) AND "HIV"[Mesh] \\
\hline Childbearing decision AND HIV \\
\hline Childbearing decision AND AIDS \\
\hline Reproductive AND decision making AND HIV \\
\hline Reproductive AND decision making AND AIDS \\
\hline Fertility intention AND HIV \\
\hline Fertility intention AND AIDS \\
\hline Fertility AND decision making AND HIV \\
\hline Fertility AND decision making AND AIDS \\
\hline Child desire AND AIDS \\
\hline Child desire AND HIV \\
\hline Reproductive choice AND women living with HIV \\
\hline
\end{tabular}

\section{Study Screening}

The study screening was completed between November 2017 and February 2019 using a structure process[50], first by title review, then by abstract review, and finally by full text review by four pairs of experienced reviewers. The study titles retrieved from the database searches were first independently screened by paired reviewers to identify the studies that appear to meet the inclusion criteria. For the included titles, the reviewers then evaluated the abstracts for inclusion, reviewing a different group than the previous step. Finally, the reviewers assessed the full text of the remaining articles by strictly applying the inclusion and exclusion criteria. During each round, a third reviewer checked the work of each review pair for possible errors. If there was disagreement between the paired reviewers, the document advanced to the next review process during the title and abstract phases. The primary investigator checked the level 
of agreement between review pairs for the title and abstract phases, with the goal of $95 \%$ agreement. In the full text review, the excluded and included articles were checked by another pair of reviewers as a final verification. The PRISMA diagram provides an overview of the inclusion and exclusion process (see Fig. 1).

\section{Quality Assessment}

The research team included the appropriate methods and content experts[51] to develop a clear, justified, and focused review question[52] with realistically defined objectives[53] (Toye et al., 2014) for an expansive search strategy to identify relevant research.[54] Then, four pairs of reviewers independently screened the articles applying the inclusion criteria and assessing the risk of bias. Discrepancies were solved by AHZ and JLM; and then reviewed by an external researcher. Each article included in the full text analysis was peer-reviewed (AHZ and JLM), and independently assessed (AHZ, JLM, and PAP) for methodological criteria with the 10-item Critical Appraisal Skills Programme (CASP) qualitative checklist. [55] Consensus was required for inclusion of an article. Congruence between theory, methods, and analysis, researcher reflexivity, and ethical protections were assessed with the JBI Critical Appraisal Checklist for Qualitative Research Studies.[29] The checklists were applied to assess the minimum quality of study methods, adequacy of ethical protections, and trustworthiness[56] rather than to exclude interview data from papers as this could introduce bias.[57]

\section{Data Extraction}

The primary focus for the data extraction was the results and the conclusions sections of each article. General data extracted from the articles, line-by-line, were assembled in an Excel spreadsheet, including study setting, aim, participants, study design, direct quotes, and key findings. Then, the data were imported into Nvivo ${ }^{\circledR}$ to electronically recorded the codes, and the emergence of the themes from the coding.[58] The level of coding was words, phrases, and sentences.

\section{Data Synthesis}

Following the recommendations of Sandelowski and Barroso[28], the data analysis was a circular rather than linear to permit the movement between the emergent themes from the findings[59] with the creation of a taxonomy of findings with sustained comparisons, concepts translated in vivo, and imported concepts.[60]. The taxonomy is comprised of items that have different semantic relations, either within the same or between different categories in each domain.

In a staged process[61], two researchers (AH and JL) conducted an inductive analysis[62] followed by a deductive process with the results discussed and triangulated with two other authors (JE and SC), and checked by two additional researchers (PAP and KDC). The relationships, similarities, and dissonances were synthesized across studies. During this process, key concepts and conceptual themes were identified. Relevant findings from one study were compared to the themes, metaphors, and concepts in the other studies. As recommended by King[63], the thematic analysis was not finalized until all the data were reviewed and the codes checked multiple times. 


\section{Trustworthiness}

The protocol for this QRS was designed to maximize descriptive validity (factual accuracy of data), interpretive validity (validity referred to in descriptions of member checking), theoretical validity (credibility of researcher interpretations), and pragmatic validity (utility and transferability of knowledge). In this regard, several techniques were incorporated into the protocol such as the check and rechecks of the initial search results, maintenance of an audit trail, multiple researchers completing each article appraisal, expert peer review, team 'huddles' to discuss individual and comparative appraisals, and ongoing discussion and negotiation.[64-67]

\section{Ethics}

Ethics approval was not necessary as all the search was conducted in public databases. There were no human subjects in this study. However, the included studies were evaluated for ethical standards with the JBI Checklist. Each of these studies was approved by an ethics committee or institutional review board.

\section{Results}

Based on the search strategy protocols, a total of 4,198 potential articles were identified through the systematic literature searches and reduced to a sample of 8 qualitative articles were included for analysis (see Table 2). Each of the articles in the sample met the requirement for inclusion using the CASP checklist while one article[68], was assessed as weak in theoretical and methodological congruence with the JBI checklist. The articles represented 1,333 participants with data from 10 countries with about half the studies principally from urban areas of the United States. From the data, 45 subthemes emerged, and these were organized into 15 themes. These themes were then grouped into three meta-themes to explain the factors influencing the reproductive decision-making of WLH: 1) Shattered identity, 2) Barriers, inequities, and misinformation, 3) Coping, Resiliency, and Support (see Table 3). When women learn about their HIV positive diagnosis, their meaning in life is changed, and their identity is altered. Yet, motherhood remains one of their main goals in in life. Reproductive decision-making is a complex process influenced by many factors. The facilitators help WLH cope with their new situation to become more resilient, while others act as barriers that make their situation difficult to manage. 
Table 2

Summary of Included Studies

\begin{tabular}{|c|c|c|c|}
\hline $\begin{array}{l}\text { AUTHOR/S } \\
\text { YEAR }\end{array}$ & $\begin{array}{l}\text { SAMPLE / } \\
\text { SETTING }\end{array}$ & $\begin{array}{l}\text { METHODOLOGY } \\
\text { AND METHODS }\end{array}$ & MAIN FINDINGS \\
\hline $\begin{array}{l}\text { Barnes \& } \\
\text { Murphy } \\
(2009) \text {. }\end{array}$ & $\begin{array}{l}80 \text { WLH, } \\
\text { childbearing } \\
\text { age, in } \\
\text { Oakland, } \\
\text { Chicago and } \\
\text { Illinois } \\
\text { (United } \\
\text { States). }\end{array}$ & $\begin{array}{l}\text { Grounded theory. } \\
\text { Data collection: } \\
\text { Interviews (semi- } \\
\text { structured). Dates: } \\
1995 \text { to } 2000 \text {. }\end{array}$ & $\begin{array}{l}\text { WLH reproductive decisions are based on their } \\
\text { judgment of the relative weight of positive } \\
\text { aspects of motherhood versus the often- } \\
\text { negative pressures of social and public } \\
\text { opinion. }\end{array}$ \\
\hline $\begin{array}{l}\text { Barnes } \\
(2013) .\end{array}$ & $\begin{array}{l}36 \text { WLH, } \\
\text { mothers, } \\
\text { from } \\
\text { Oakland and } \\
\text { Rochester } \\
\text { (United } \\
\text { States). }\end{array}$ & $\begin{array}{l}\text { Grounded theory. } \\
\text { Data collection: } \\
\text { Interviews (in- } \\
\text { depth). Dates: } \\
2005 \text { to } 2009 \text {. }\end{array}$ & $\begin{array}{l}\text { WLH who had living children experienced } \\
\text { longevity from fulfilling dreams of seeing their } \\
\text { children grow up despite the unique } \\
\text { challenges from their HIV status. The } \\
\text { longevity offered possibilities for regaining } \\
\text { contact with children who had been given up } \\
\text { for adoption, were or had been in foster care, } \\
\text { or lived with family members. WLH felt living } \\
\text { longer offered more possibilities of becoming } \\
\text { a mother with pregnancy, but opportunities } \\
\text { were complicated with reconciling past } \\
\text { reproductive experiences and poor choices. }\end{array}$ \\
\hline $\begin{array}{l}\text { Campero et } \\
\text { al. (2010). }\end{array}$ & $\begin{array}{l}\text { Heterosexual } \\
20 \text { WLH and } \\
20 \text { men > } \\
18 \text { years old } \\
\text { in four } \\
\text { states of } \\
\text { Mexico. }\end{array}$ & $\begin{array}{l}\text { Grounded theory. } \\
\text { Data collection: } \\
\text { Interviews (in- } \\
\text { depth). Dates: } \\
2003 \text { to } 2004 .\end{array}$ & $\begin{array}{l}\text { Limited support and counseling is a barrier to } \\
\text { exercising sexual and reproductive rights of } \\
\text { participants, especially women. Principal } \\
\text { issues included feeling frustrated and } \\
\text { confused, fear of re-infection, limited } \\
\text { information, lack of power to negotiate } \\
\text { condom use, social stigma and } \\
\text { discrimination, and limited access to services } \\
\text { and technologies. }\end{array}$ \\
\hline
\end{tabular}




\begin{tabular}{|c|c|c|c|}
\hline $\begin{array}{l}\text { AUTHOR/S } \\
\text { YEAR }\end{array}$ & $\begin{array}{l}\text { SAMPLE / } \\
\text { SETTING }\end{array}$ & $\begin{array}{l}\text { METHODOLOGY } \\
\text { AND METHODS }\end{array}$ & MAIN FINDINGS \\
\hline $\begin{array}{l}\text { Carlsson- } \\
\text { Lalloo et al. } \\
\text { (2016). }\end{array}$ & $\begin{array}{l}18 \\
\text { qualitative } \\
\text { studies with } \\
\text { a total of } \\
588 \text { WLH } \\
\text { interviewed } \\
\text { from } \\
\text { wealthier } \\
\text { countries } \\
\text { outside the } \\
\text { Asian and } \\
\text { African } \\
\text { continents. }\end{array}$ & $\begin{array}{l}\text { Meta- } \\
\text { ethnography. Data } \\
\text { collection: } \\
\text { Interview and } \\
\text { observational } \\
\text { data. Dates: } 1997 \\
\text { to } 2012 . \\
\text { Locations: USA } \\
\text { (11), Canada (2), } \\
\text { UK (2), Australia } \\
\text { (1), Ireland (1), } \\
\text { and Brazil (1). } \\
\text { Two systematic } \\
\text { searches } \\
\text { (sexuality and } \\
\text { reproduction) in } \\
\text { CINAHL and } \\
\text { MEDLINE. Articles } \\
\text { assessed with } \\
\text { Critical Appraisal } \\
\text { Skills Programme. }\end{array}$ & $\begin{array}{l}\text { HIV infection is a burden in relation to } \\
\text { sexuality and reproduction. The weight of the } \\
\text { burden can be heavier or lighter. Conditions } \\
\text { making the HIV burden heavier included: HIV } \\
\text { as a barrier, feelings of fear and loss, whereas } \\
\text { motherhood, spiritual beliefs, and supportive } \\
\text { relationships make the HIV burden lighter. }\end{array}$ \\
\hline $\begin{array}{l}\text { Cuca \& Rose } \\
\text { (2016). }\end{array}$ & $\begin{array}{l}20 \text { WLH, > } \\
18 \text { years old, } \\
\text { diagnosed at } \\
\text { least } 1 \text { year } \\
\text { prior to } \\
\text { study; } \\
\text { pregnant at } \\
\text { least once } \\
\text { since their } \\
\text { HIV } \\
\text { diagnosis } \\
\text { living in San } \\
\text { Francisco } \\
\text { (United } \\
\text { States). }\end{array}$ & $\begin{array}{l}\text { Grounded theory } \\
\text { and situational } \\
\text { analysis. Data } \\
\text { collection: } \\
\text { Interviews (in- } \\
\text { depth) and } \\
\text { observations. } \\
\text { Dates: } 2009 \text {, } \\
\text { October to 2010, } \\
\text { February; and } \\
\text { 2012, October and } \\
\text { 2013, February. }\end{array}$ & $\begin{array}{l}\text { Reproductive choices are made in situations } \\
\text { of chaos, instability, and stigmatization. For } \\
\text { some women, providers are sources of } \\
\text { stigma. Participants demonstrated resistance } \\
\text { to stigmatization, through building supportive } \\
\text { communities and developing trusting } \\
\text { relationships with HIV providers. }\end{array}$ \\
\hline $\begin{array}{l}\text { Giles et al. } \\
(2009) \text {. }\end{array}$ & $\begin{array}{l}45 \text { HIV- } \\
\text { infected } \\
\text { women ages } \\
18-44 \text { living } \\
\text { in } \\
\text { Melbourne, } \\
\text { Australia. }\end{array}$ & $\begin{array}{l}\text { Content analysis. } \\
\text { Data collection: } \\
\text { Interviews (semi- } \\
\text { structured } \\
\text { questions). Dates: } \\
2005 \text { to } 2006 \text {. }\end{array}$ & $\begin{array}{l}\text { The } 15 \text { women who had their children after } \\
\text { their HIV diagnosis engaged in significant } \\
\text { work including surveillance and safety work to } \\
\text { minimize stigma and infection, information } \\
\text { work to inform decisions and actions, } \\
\text { accounting work to calculate risk and benefit, } \\
\text { hope and worry work concerning a child's } \\
\text { infection status and impact of interventions, } \\
\text { work to redefine an acceptable maternal } \\
\text { identity, work to prepare an alternative story to } \\
\text { counter the disclosure effect of the } \\
\text { intervention and emotional work to reconcile } \\
\text { guilt when considering these interventions. }\end{array}$ \\
\hline
\end{tabular}




\begin{tabular}{|c|c|c|c|}
\hline $\begin{array}{l}\text { AUTHOR/S } \\
\text { YEAR }\end{array}$ & $\begin{array}{l}\text { SAMPLE / } \\
\text { SETTING }\end{array}$ & $\begin{array}{l}\text { METHODOLOGY } \\
\text { AND METHODS }\end{array}$ & MAIN FINDINGS \\
\hline $\begin{array}{l}\text { Jean et al. } \\
(2016) .\end{array}$ & $\begin{array}{l}19 \text { HIV- } \\
\text { infected } \\
\text { sexually } \\
\text { active } \\
\text { women ages } \\
18-45 \text { living } \\
\text { in Southern } \\
\text { Florida, } \\
\text { (United } \\
\text { States). }\end{array}$ & $\begin{array}{l}\text { Collaborative with } \\
\text { thematic analysis. } \\
\text { Data collection: } \\
\text { Interviews (open- } \\
\text { ended questions). } \\
\text { Date: Unknown. }\end{array}$ & $\begin{array}{l}\text { Decisions to conceive are influenced by } \\
\text { women and partners; knowledge and use of } \\
\text { safer conception practices are low. Discussion } \\
\text { and support from partners, family and } \\
\text { providers is limited and diminished by stigma } \\
\text { and nondisclosure. }\end{array}$ \\
\hline $\begin{array}{l}\text { Keegan et al. } \\
\text { (2005). }\end{array}$ & $\begin{array}{l}21 \mathrm{WLH} \\
\text { ages } 22-54 \\
\text { living in the } \\
\text { United } \\
\text { Kingdom }\end{array}$ & $\begin{array}{l}\text { Interpretative } \\
\text { phenomenological } \\
\text { analysis. Data } \\
\text { collection: } \\
\text { Interviews (in } \\
\text { depth and semi- } \\
\text { structured). Dates: } \\
\text { Unknown. }\end{array}$ & $\begin{array}{l}\text { Themes identified included: (1) difficulties } \\
\text { with sexual functioning, specifically lowered } \\
\text { libido and enjoyment and reduced intimacy; } \\
\text { (2) barriers to forming new relationships: fears } \\
\text { of HIV disclosure, fears of infecting partners; } \\
\text { (3) coping strategies: included relationship } \\
\text { avoidance and having casual partners to } \\
\text { avoid disclosure; (4) safer sex: personal } \\
\text { dislike of condoms, lack of control, lack of } \\
\text { suitable alternatives. Women experienced a } \\
\text { range of sexual and relationship difficulties } \\
\text { that appear to be relatively unchanged despite } \\
\text { the advent of HAART. }\end{array}$ \\
\hline $\begin{array}{l}\text { Kelly et al. } \\
(2011) .\end{array}$ & $\begin{array}{l}6 \text { women } \\
\text { and } 4 \text { men } \\
\text { living with } \\
\text { HIV with a } \\
\text { reproductive } \\
\text { trajectory in } \\
\text { Northern } \\
\text { Ireland. }\end{array}$ & $\begin{array}{l}\text { Qualitative } \\
\text { narrative } \\
\text { approach. Data } \\
\text { collection: } \\
\text { Interviews (in- } \\
\text { depth) Dates: } \\
2008 \text { to } 2009 \text {. }\end{array}$ & $\begin{array}{l}\text { Personal priorities and meanings are central } \\
\text { to the negotiation of risk in sexual } \\
\text { relationships, in which biomedical } \\
\text { understandings of are balanced against a } \\
\text { broader set of social expectations and desires. } \\
\text { The need to re-negotiate a loving relationship } \\
\text { and reproductive desires along with a desire } \\
\text { for physical pleasure, a dislike of condoms } \\
\text { within stable relationships and a desire to } \\
\text { conceive without medical intervention were all } \\
\text { given as justifications for unprotected sex in } \\
\text { order to conceive within the context of sero- } \\
\text { different relationship. Religious faith help } \\
\text { WLH to embrace the uncertainties of } \\
\text { reproduction in the context of HIV. }\end{array}$ \\
\hline
\end{tabular}




\section{$\begin{array}{llll}\text { AUTHOR/S } & \text { SAMPLE / } & \text { METHODOLOGY } & \text { MAIN FINDINGS } \\ \text { SETTING } & \text { AND METHODS } & \end{array}$ \\ YEAR}

Kelly et al. (2014).
10 women

and 5 men

living with

HIV, different

stages of

disease,

during

reproductive

trajectory in

Ireland.
Qualitative

narrative

approach. Data

collection:

Interviews (in-

depth). Dates:

2007 to 2010.

HIV positive women desire for children reflects the cultural norm of motherhood as a natural desire and a social expectation. Pregnancy signifies normality and the natural order to completing a committed relationship. The decision to become pregnant is taken against a backdrop of increased confidence in the role of treatment in lengthening lives and protecting babies from infection. Love, commitment, and desire to conceive without medical interventions, alongside the added security of an undetectable viral load, significantly impact on women's decisions to have unprotected sex to conceive. HIV positive women are more hesitant than men to take the risk of unprotected sex with their negative partner. Achieving an undetectable viral load to protect their children from HIV infection became a major goal. Stigma continues to dominate the symbolic significance of HIV.

Grounded theory. Data collection: Interviews (in depth). Dates: 1998, December to 1999 , August.
Kirshenbaum et al. (2004).

56 women ages $20-55$ living in LOS Angeles, Milwaukee, New York, and San

Francisco (United States)
Risk of vertical transmission was perceived by WLH but overestimated.

Motherhood is desired, but decision-making is impacted by beliefs about vertical transmission, strategies, stigma, religious values, attitudes of partners and health care providers, and the impact of the mother's health and longevity on the child. When women do not want children after their diagnosis, vertical transmission risk is the main reason (but most of these women already had children). Those who become pregnant or desired children after diagnosis were more confident in the risk reduction strategies and often do not already have children.

\begin{tabular}{|c|c|c|}
\hline $\begin{array}{l}\text { Leyva-Moral } \\
\text { et al., (2017). }\end{array}$ & $\begin{array}{l}12 \\
\text { qualitative } \\
\text { studies, with } \\
50 \text { women, } \\
\text { published in } \\
\text { peer- } \\
\text { reviewed } \\
\text { journals } \\
\text { conducted in } \\
\text { Brazil and } \\
\text { the New York } \\
\text { (United } \\
\text { States). }\end{array}$ & $\begin{array}{l}\text { Systematic review } \\
\text { of } 12 \text { databases } \\
\text { with meta- } \\
\text { synthesis. Dates: } \\
2005 \text { to } 2015 . \\
\text { Articles assessed } \\
\text { with Critical } \\
\text { Appraisal Skills } \\
\text { Programme. }\end{array}$ \\
\hline
\end{tabular}

For pregnant WLH, pregnancy evolves as a mediated experience of commitment and dedication. The vital life experience of pregnancy is defined as an interplay of emotions, coping strategies, and feelings of satisfaction. Pregnancy in WLH is experienced and impacted by societal beliefs, as the women focuses all their efforts to take care of themselves and their babies. 


\begin{tabular}{|c|c|c|c|}
\hline $\begin{array}{l}\text { AUTHOR/S } \\
\text { YEAR }\end{array}$ & $\begin{array}{l}\text { SAMPLE / } \\
\text { SETTING }\end{array}$ & $\begin{array}{l}\text { METHODOLOGY } \\
\text { AND METHODS }\end{array}$ & MAIN FINDINGS \\
\hline $\begin{array}{l}\text { Leyva-Moral } \\
\text { et al. (2018). }\end{array}$ & $\begin{array}{l}42 \text { research } \\
\text { papers, } 16 \\
\text { with } \\
\text { qualitative } \\
\text { data about } \\
\text { reproductive } \\
\text { decisions of } \\
\text { WLH } \\
\text { published in } \\
\text { peer- } \\
\text { reviewed } \\
\text { journals, (14 } \\
\text { US, } 1 \text { UKK, } 1 \\
\text { Ireland). }\end{array}$ & $\begin{array}{l}\text { Systematic review } \\
\text { of qualitative and } \\
\text { quantitative } \\
\text { studies. Dates: } \\
1985 \text { to } 2016 . \\
\text { Articles assessed } \\
\text { with Critical } \\
\text { Appraisal Skills } \\
\text { Programme. }\end{array}$ & $\begin{array}{l}\text { Socio-demographic, health status and } \\
\text { pregnancy, religion and spirituality, beliefs and } \\
\text { attitudes about antiretroviral therapy, } \\
\text { clinicians, significant others, motherhood and } \\
\text { fulfillment, fear of perinatal infection and } \\
\text { infection of partner(s), birth control and } \\
\text { pregnancy management are the factors that } \\
\text { influence the reproductive decision-making } \\
\text { process in WLH. }\end{array}$ \\
\hline $\begin{array}{l}\text { Sanders, } \\
\text { (2008). }\end{array}$ & $\begin{array}{l}9 \text { WLH } \\
\text { mothers } \\
\text { ages } 34-53 \\
\text { living in New } \\
\text { York (United } \\
\text { States). }\end{array}$ & $\begin{array}{l}\text { Phenomenology. } \\
\text { Data collection: } \\
\text { Informant } \\
\text { interviews. Dates: } \\
2006 .\end{array}$ & $\begin{array}{l}\text { The experience of pregnancy for a woman } \\
\text { with HIV is one fraught with isolation, anxiety, } \\
\text { and distrust, but it is also one of hope for the } \\
\text { normalcy that motherhood may bring. }\end{array}$ \\
\hline $\begin{array}{l}\text { Sanders, } \\
\text { (2009). }\end{array}$ & $\begin{array}{l}9 \text { WLH } \\
\text { mothers } \\
\text { ages 34-53 } \\
\text { living in New } \\
\text { York (United } \\
\text { States). }\end{array}$ & $\begin{array}{l}\text { Descriptive } \\
\text { qualitative. Data } \\
\text { collection: } \\
\text { Secondary data } \\
\text { analysis to } \\
\text { explore the lived } \\
\text { experience of } \\
\text { pregnancy after } \\
\text { diagnosis with } \\
\text { HIV (thematic } \\
\text { analysis). Dates: } \\
\text { 2006. }\end{array}$ & $\begin{array}{l}\text { Three themes: (a) unprotected sexual relations } \\
\text { with the intent to become pregnant, (b) } \\
\text { shifting responsibility for condom use as the } \\
\text { relationship progressed, and (c) insufficient } \\
\text { knowledge of how to reduce partner } \\
\text { transmission risk in relation to childbearing. } \\
\text { Participants were knowledgeable about the } \\
\text { means to minimize transmission to the fetus. }\end{array}$ \\
\hline $\begin{array}{l}\text { Siegel et al., } \\
(2006) \text {. }\end{array}$ & $\begin{array}{l}284 \text { WLH } \\
\text { ages } 20-45 \\
\text { living in New } \\
\text { York (United } \\
\text { States). }\end{array}$ & $\begin{array}{l}\text { Content analysis. } \\
\text { Data collection: } \\
\text { Focused } \\
\text { interviews of } \\
\text { WLH. Dates: } 146 \\
\text { interviews from } \\
\text { 1994, October to } \\
\text { 1996, November } \\
\text { (prior to the } \\
\text { advent of HAART } \\
\text { regimens) and } \\
138 \text { interviews } \\
\text { from March } 2000 \\
\text { to April } 2003 \\
\text { (after widespread } \\
\text { availability of } \\
\text { HAART). }\end{array}$ & $\begin{array}{l}\text { Women in general reported a decreased } \\
\text { sexual activity, a loss of sexual interest, and a } \\
\text { diminished sense of sexual attractiveness } \\
\text { following their HIV infection. The reasons for } \\
\text { why they had discontinued sexual activity or } \\
\text { were no longer interested in sex, included } \\
\text { anxiety about HIV transmission, a loss of } \\
\text { freedom and spontaneity during sex, fears of } \\
\text { emotional hurt, not wanting the hassle of } \\
\text { sexual relationships, a loss of sexual interest, } \\
\text { and a diminished sense of sexual } \\
\text { attractiveness. The types of changes in their } \\
\text { sexuality did not differ between women in the } \\
\text { pre-HAART and HAART eras. }\end{array}$ \\
\hline
\end{tabular}

Abbreviations: WLH = Women living with HIV 


\begin{tabular}{|c|c|c|c|}
\hline $\begin{array}{l}\text { AUTHOR/S } \\
\text { YEAR }\end{array}$ & $\begin{array}{l}\text { SAMPLE / } \\
\text { SETTING }\end{array}$ & $\begin{array}{l}\text { METHODOLOGY } \\
\text { AND METHODS }\end{array}$ & MAIN FINDINGS \\
\hline $\begin{array}{l}\text { Walulu, \& Gill } \\
(2011) .\end{array}$ & $\begin{array}{l}15 \text { WLH, } \\
\text { mothers, } \\
\text { living in the } \\
\text { Midwest } \\
\text { (United } \\
\text { States), at } \\
\text { least } \\
18 \text { years old, } \\
\text { with at least } \\
\text { one child } \\
\text { living at } \\
\text { home. }\end{array}$ & $\begin{array}{l}\text { Grounded theory. } \\
\text { Data collection: } \\
\text { Interviews (in- } \\
\text { depth). Dates: } \\
\text { Unknown. }\end{array}$ & $\begin{array}{l}\text { The core category is Living for My Children, } \\
\text { which involves five areas: Knowing My } \\
\text { Diagnosis, Living with HIV, Taking Care of } \\
\text { Myself, Seeking Support, and Being There for } \\
\text { My Child }\end{array}$ \\
\hline $\begin{array}{l}\text { Wesley et al., } \\
(2000) \text {. }\end{array}$ & $\begin{array}{l}25 \mathrm{WLH}, \\
\text { mothers, at } \\
\text { least four } \\
\text { months } \\
\text { postpartum } \\
\text { living in New } \\
\text { Jersey } \\
\text { (United } \\
\text { States). }\end{array}$ & $\begin{array}{l}\text { Content analysis. } \\
\text { Data collection: } \\
\text { Interviews (semi } \\
\text { structured) based } \\
\text { on Fishbein's } \\
\text { Theory of } \\
\text { Reasoned Action. } \\
\text { Dates: Unknown. }\end{array}$ & $\begin{array}{l}\text { Motherhood is viewed as a joy and as a } \\
\text { means of meeting unmet needs but there is a } \\
\text { concern about children's well-being. HIV } \\
\text { infection has a minor role in HIV-positive } \\
\text { women's lives. }\end{array}$ \\
\hline
\end{tabular}


Table 3

Meta-Themes, Themes, and Subthemes

META-THEMES

Shattered Identity
Womanhood

Motherhood

\section{THEMES}

SUB-THEMES

I'm shocked

I don't feel like a woman anymore

Permanence of HIV

Loss of normality

Broken plans

Reduced sexual desire

Becoming mothers as a route to normality

Missed mothering opportunities

Motherhood as a social responsibility

Motherhood as a personal desire (value \& identity)

Barriers, Inequities, \& Information

\begin{tabular}{|c|c|c|}
\hline Institutional barriers & \multicolumn{2}{|c|}{ External barriers for accessing care } \\
\hline \multirow[t]{3}{*}{ Clinician barriers } & \multicolumn{2}{|c|}{ Negative support from healthcare providers } \\
\hline & \multicolumn{2}{|c|}{ They never asked me if I want to have a baby } \\
\hline & \multicolumn{2}{|c|}{ Coercion and concealment } \\
\hline \multirow{2}{*}{$\begin{array}{l}\text { Inadequate } \\
\text { information }\end{array}$} & \multicolumn{2}{|c|}{ Need for information } \\
\hline & \multicolumn{2}{|c|}{ Weighing the different options } \\
\hline \multirow[t]{7}{*}{ Individual barriers } & \multicolumn{2}{|c|}{ Knowing about HIV } \\
\hline & \multicolumn{2}{|c|}{ Knowing about conception methods } \\
\hline & \multicolumn{2}{|c|}{ Incorrect beliefs about HIV and pregnancy } \\
\hline & \multirow{3}{*}{$\begin{array}{l}\text { Uncertainty and } \\
\text { fears }\end{array}$} & Fear of transmission \\
\hline & & Fear of birth defects \\
\hline & & Fear of leaving children alone \\
\hline & \multicolumn{2}{|l|}{ Guilt } \\
\hline Family barriers & \multicolumn{2}{|c|}{ Lack of familial support } \\
\hline \multirow[t]{3}{*}{ HIV-related stigma } & \multicolumn{2}{|c|}{ Stigmatizing and stereotyping } \\
\hline & \multicolumn{2}{|c|}{ Self-isolating and internalizing stigma } \\
\hline & \multicolumn{2}{|c|}{ Fear to disclose, will be rejected } \\
\hline
\end{tabular}




\begin{tabular}{|c|c|c|c|}
\hline META-THEMES & THEMES & \multicolumn{2}{|l|}{ SUB-THEMES } \\
\hline & Gender-based & \multicolumn{2}{|c|}{ I just want to be loved } \\
\hline & & \multicolumn{2}{|c|}{ Unequal power in relationships } \\
\hline & $\begin{array}{l}\text { Socioeconomic } \\
\text { barriers }\end{array}$ & \multicolumn{2}{|l|}{ Unstable situation } \\
\hline \multirow{15}{*}{$\begin{array}{l}\text { Coping, Resilience, \& } \\
\text { Support }\end{array}$} & Self-care and for & \multicolumn{2}{|c|}{ Treatment adherence } \\
\hline & & \multicolumn{2}{|c|}{ Changes in sexuality: protecting others from HIV } \\
\hline & & \multicolumn{2}{|l|}{ Negotiating sex } \\
\hline & & \multirow[t]{4}{*}{ Family planning } & Planned pregnancy \\
\hline & & & $\begin{array}{l}\text { Accidental and passive } \\
\text { pregnancy }\end{array}$ \\
\hline & & & $\begin{array}{l}\text { Avoiding medical } \\
\text { recommendations }\end{array}$ \\
\hline & & & $\begin{array}{l}\text { Child gets positive because } \\
\text { destiny }\end{array}$ \\
\hline & \multicolumn{3}{|c|}{ Creating empowering environments } \\
\hline & \multicolumn{3}{|c|}{ Humanized healthcare providers } \\
\hline & \multicolumn{3}{|l|}{ Partner support } \\
\hline & Hope & \multicolumn{2}{|c|}{ Medical improvement as a hope } \\
\hline & & \multicolumn{2}{|c|}{$\begin{array}{l}\text { Motherhood is a hope and being a mother is } \\
\text { reason to keep fighting HIV }\end{array}$} \\
\hline & & \multicolumn{2}{|c|}{ A new life: second opportunity, another chance } \\
\hline & \multicolumn{3}{|l|}{ Personal Choices } \\
\hline & \multicolumn{3}{|c|}{ Protection of higher power / spiritual forces } \\
\hline
\end{tabular}

\section{Shattered Identity}

WLH has a shattered identity, broken into two pieces: Womanhood and motherhood. When they learned of their positive status, they were shocked and devastated, and they no longer felt like a woman $[35,69]$. They described how HIV assaulted their bodies; stole their sense of beauty, and left the perception of dirtiness.[35] HIV was a barrier present everywhere and all the time.[35, 68, 69]

"Ah, it's just always in the bedroom, HIV. It's always there."[68] 
Sexual and reproductive decisions were modified; their desire for intimacy reduced, sexual life changed, and breastfeeding prohibited.[70] They feared disclosing their HIV status to intimate partners, family, and friends as they lost their sense of normality.[35] Their life plans were broken when HIV unexpectedly appeared.[35, 71] Their identity was subjected to self-damage that required interventions to redefine themselves. However, pregnancy was a route to being normal and a way to feel complete as a woman. $[35,70,72]$

"It [pregnancy] is sort of like a completion of myself as a woman."[72]

Childbirth is one of the most important social identities for women. $[8,16,35,73]$ WLH felt they were recognized by their community when had a child $[74,75]$ as motherhood is a cultural norm. The phenomena was therefore culturally constructed. $[8,73,74]$

"I just want one. I don't want a whole house full... I just want one baby, something that's me, a part of me. That's something that I can develop and it's still great too."[73]

Some WLH felt pushed by their families and others to become mothers.[76] Many women reported losing their children to adoption, foster care, or placement with family members due to acute illnesses, chronic diseases, and/or criminal problems such as drug abuse. These broken mothering opportunities resulted in intense guilt and emotional pain. Consequently, WLH were psychologically harmed and their identity permanently damaged. $[16,77]$

"When I was twenty-six, and I'm now forty-four, I didn't see my life going that far, so I would have made different choices. I think my main thing would have been my choice of having children. I was caught in the middle of the epidemic then. I regretted not having that child. And, you know, as life went on, I still regret it."[77]

\section{Barriers, Inequities, and Misinformation}

When making reproductive decisions, WLH encountered barriers to accessing health services[73], including difficulty obtaining appointments, lengthy wait times at appointments, problems with insurance coverage, inadequate transportation, and issues related to immigration status. Some women accessed services at new clinics with unfamiliar clinicians that resulted in uncomfortable feelings.[73]

"When you have certain insurances, it doesn't cover the places you want to go where you feel comfortable. You have to go outside and go to another person you don't even have a background on. With my oldest all my prenatal care was at Hospital X; with my youngest I had a private doctor. It's not always easy."[73]

WLH felt clinicians were not supportive, reporting HIV-related stigma. $[16,35,70,71,73,78]$ They felt their physicians were not helpful and tried to discourage them from pregnancy due to their HIV positive status. [75] The physicians never ask them about their desire to have children.[75] As a result they felt repressed, as their right to decide was coerced.[76, 78] 
"The people had pretty much brainwashed me. .. they just reared into me, telling me. .. "Right now it's not a good time. ... you ain't got a place to live, you ain't got no food, you ain't got no job, you ain't got this, you ain't got that." So, I took a look at all that and just decided to have an abortion ... [l]t hurt, you know, because I wanted to keep it but I had to take a look at the situation and say, oh okay, that, that was right, yeah, okay. That's true, though, but let me make that decision, you know, it was just like a rushed thing and. .. and I said okay, I'll have an abortion, I can't do anything else."[78]

WLH wanted more information about contraception methods and approaches to safe sex. They want to learn about their disease, including discussions with clinicians; something they were unable to find in the health system.[35, 75, 76, 79]

"I look for things that are safe $100 \%$. There have not been recorded cases of anyone becoming infected (in oral sex) so I thought that's $100 \%$ safe. So like a month later I was reading another one of these small leaflets and it says although the risk is small there is some risk and I started to become a bit paranoid."[79]

Their general knowledge about HIV, varied; however, WLH commonly believed they cannot be mothers. They had the wrong beliefs about the impact of HIV on their ability to become pregnant.[69, 73, 75]

"Like most women, I always wanted to have a baby, but thought it wasn't an option anymore when I was diagnosed with HIV."[75]

In terms becoming pregnant, WLH feared the risk of transmission to their child or partner, worried about possible health complications, and anticipated adverse effects from HAART.[8, 16, 70, 71, 75, 76] Yet, they still wanted to become pregnant and give birth as naturally as possible. Although some WLH understood the transmission risk was low, they remained fearful and worried. $[8,16,70-72,75,76]$

"My other fear is that my baby will come out positive."[72]

In contrast, other women considered HIV to be a death sentence as they considered the psychological impact of their health and their longevity for their children when making decisions about pregnancy.[8, 16 , $35,69,71,72]$

"Am I going to get sick? Am I going to die, and the baby is going to live? I think about all of this." [72]

WLH also confronted overwhelming guilt about their HIV negative partner, past mistakes such as drug abuse, or previous decisions to give up their children for adoption. $[8,16,35,71,77]$ Yet again, WLH expressed their desire to change the past by becoming good mothers.

"My last daughter was also born tox-positive for cocaine... and I want to change that... I want to make sure it doesn't happen again."[71]

Generally, WLH did not feel supported by family members as they did not want to hear about their pregnancy. As family members assumed they cannot have babies, the WLH experienced stigmatizing 
behaviors and comments. $[8,16,73,78,80]$

"My mom told me to erase it out of my head... And it was always the same thing: I was selfish."[78].

This stigma was also present in interactions with partners and clinicians. $[8,16,35,69,71,73,75,77,78]$ As internalized stigma developed, WLH self-isolated as they feared disclosing their HIV status even to seek advice from clinicians about reproductive decisions. [78] Fear of rejection made WLH especially reluctant to disclose their HIV status to partners and friends when speaking about pregnancy.[8, 35, 69, $73,75-77]$

"Stigma ...makes that person not want to talk about it [pregnancy]. So you have already labeled me, you already said how you feel about it. If we are talking, and you already said something bad about someone who has the virus - why would I open up to you? You're going to talk about me. And see my feelings are going to get hurt."[73]

WLH want to be loved and to have an intimate partner.[35] But occasionally their decisions were coerced by men, who forced WLH to have unprotected sex or to become pregnant.[35, 73] When men knew they were HIV positive or when they became pregnant, the relationship was disrupted. In these cases, some woman felt abandoned or, on the contrary, others had subsequent unwanted pregnancies.[35]

"I was always the one pushing him to use condoms, and he didn't want to. Eventually when we were living together, I just stopped. It's not always going to be my responsibility to push that."[80]

Finally, WLH sometimes experienced homelessness, poverty, domestic violence, drug abuse, and other marginalizing situations. Instability in their lives made reproductive decisions difficult, including whether or not to continue with unplanned pregnancies.[71, 78] Some women believed having a child without the resources to create a stable family environment was irresponsible.[71]

"It's not an irresponsible thing to have a child. It's an irresponsible thing to have a child without a father, without a decent income, without a place to live and without the ability to take care of this child... while dealing with your own stuff."[71]

\section{Coping, Resiliency, and Support}

Sexuality and reproduction overlap with love, intimacy, and commitment but all are disturbed by HIV. As the WLH did not want to harm others by transmitting their HIV, they either searched for approaches for safe sex or chose celibacy.[35] WLH reported barriers for contraceptives such as cost and rejection by their partner.[74] The women needed strategies to negotiate safe sex.[35, 74] This process was described as passive negotiation in studies.[35, 79]

"I just told them it was because you don't know where I come from, I don't know where you come from, so it is good to be careful and at the same time I don't want to get pregnant."[79] 
WLH considered planning for pregnancy necessary to protect their health, as well as their partner, prior to attempting to conceive.[73] Nonetheless, some women believed reproductive decisions were passive plans, even accidental situations; and they needed to assume responsibility for the consequences.[71, 73] Some WLH reported lacking confidence in HAART to reduce the risk of mother-to-child transmission.[76] as they believed that if the child gets infected this is destiny.[71]

"It's not really a planning thing, they just talk about it if they want to have a baby, and if it happens then it happens."[73]

Other WLH preferred to conceive without medical intervention so they engaged in unprotected sex. For these women, love and commitment with their partners was more important than the risk, as childbirth should not be medicalized.[73, 75]

"When you find a guy and you feel comfortable with them and they accept what is going on with you, you cannot use condoms, even though you know you can get re-infected...when you are blinded by that person you take risks, I take risks, and say ain't nothing going to happen to me, ain't nothing happened to me so far so what the hell."[73]

Sharing their status with others was a coping strategy identified by WLH to accept their diagnosis. Creating empowering environments such as support groups for people to understand their situation appeared to be helpful.[78]

"Surrounding myself around people that's HIV... It helps me a lot, it chills me down."[78]

However, intimate partners were the most important person for reproductive decision-making as they helped WLH feel self-confidence as they engaged in their decision-making process.[70, 73, 75] In some cases, WLH reported their relationships were stronger following HIV diagnosis due to the increased partner support.[70]

"He's [partner] with me, he's got my back $110 \%$. So anything I decide I want to do he supports me -- there's not a lot of men that do that. When I met and let him know what my status was, he told me "and what?" He didn't see my status he saw that person that I was, that I am, he knows that I am a good person and that's what."[73]

Despite the challenges, WLH sought advice when considering pregnancy as they wanted to make their own good decision. They were not discouraged from wanting children by negative input from family members or their clinicians.[73]

"I really don't care for... what family has to say, because ....as a grown individual you have to be grown enough... to make your own decisions."[73]

However, WLH shared their decision with God as they believed their situation resulted from the plan God had for them.[8, 16, 35, 69, 71, 77] God plays an essential role in reproductive decision-making as 'He' will 
protect their children, so the final decision is shared with 'Him.'[69] WLH felt relief because they could depend on spiritual forces, including greater protectiveness from God's power.

"But basically, it's a decision I made with my higher power. I just ask God to show me what to do."[16]

When WLH were aware of medical advancements related to pregnancy, the possibility of becoming a mother was real.[75] Mothering gave them a reason to continue their fight against HIV as they wanted to live, and they could be stronger.[8, 16, 35, 69] Moreover, some WLH felt they received a second chance, as they has an opportunity to correct their past parenting mistakes and to catch up on their missed mothering opportunities.[16, 77]

"However, over the years, with improvements in treatment and people with HIV living longer, it started to feel possible. The doctors told us that the risk of the baby having HIV has gone down to $1 \%$."[75]

\section{Discussion}

Once a woman is diagnosed with HIV, life changed, and identity altered. Many WLH canceled plans for children due to knowledge deficits, misinformation, stigma, and/or judgment. Being a mother is defined by their feminine identity as well as a social expectation defined by cultural structures. As such, WLH seek to save their role as "good mothers" to stabilize their identity and maintain their social value threatened by HIV.[6] In general, people living with HIV experience a wide range of negative feelings such as emotional stress[81], fear[82], guilt[76], hopelessness[83], and internalized stigma.[84] In the case of WLH who also experienced broken mothering opportunities that exacerbated their guilt and emotional pain, the situation is worsened.

In consonance with the available evidence, this study found there is a lack of knowledge about the relationship between HIV, sexual health, and reproductive decision-making.[21, 85] Consequently, WLH believed they should not become mothers, and their reproductive desires were broken by the force of this belief.[85] As Fransen and Guarinieri[23] concluded, the desire WLH to have children is not influenced by the diagnosis, but their ability to act upon this desire is blocked by the stigmatization manifested by the negative attitudes of friends and family. Moreover, their sexual life is modified, and they lose the feeling of normality. WLH experience greater sexual problems including decreased sexual function and diminished sexual desire, activity, and satisfaction compared to uninfected women.[86]

Clinicians have a role in the decision-making process as the WLH wanted their support to determine the possibility of safely having a child.[69] Their role is essential in changing not only the perception of risk, but also in helping WLH make an informed decision, based on the right information and access to safe conception and pregnancy.[23, 85]. However, some studies suggested there is a persistent stigma related to pregnancy in HIV-affected couples such that clinicians are more likely to ask their patients about contraception rather than reproductive intentions.[17] But, WLH want to be viewed as a whole person, not only as a diseased entity.[15] For these reasons, WLH perceive the clinician assumptions about their sexual practices and reproductive goals as barriers to reproductive discussions. Lassi et al.[87] 
recommended clinicians engage in preconception counseling for women of reproductive age when they test HIV-positive as well as screening with their partners prior to pregnancy. This could be accomplished with comprehensive reproductive health counseling to WLH, including teaching clinicians how to be authentically present and engaged in shared decision-making with HIV-affected couples.[17]

From this synthesis, stigma is evidenced in the interactions WLH reported with friends, families, partners, and clinicians.[17, 25] This leads to marginalization, stress, uncertainty, and isolation.[8] The WLH experience insecurity about their prognoses, potential treatments, social relationships, and personal identity.[88] There was significant stigma for WLH resulting from the barriers to accessing preventive and health services.[89] WLH live with similar concern about clinicians and uncertainty about health services as people living with acute and chronic conditions.

Reproductive decision-making for each WLH is unique, as they use their repertoire of coping mechanisms. When entering a support group for example, they can become part of a larger reality which offers peer support and provides collective strength.[21] Also, partner support is indispensable as they are identified as the most important person to make the decision about having a baby.[12] Although clinicians are not actively involved in reproductive decision-making with many WLH, medical advancements offer WLH another opportunity to correct past parenting mistakes as hope to become a good mother. Hope is capable of changing the woman's life and encouraging them to go forward[90] in fighting the HIV.

Generally, WLH wanted to make their own reproductive decisions despite the large number of barriers while recognizing they need more facilitators. The women frequently noted spiritual forces protected them, as well as planned their lives. As such, these women felt a strong duty to care for their babies that contributed to increased self-care. The risk of transmitting the infection to a fetus, or their partner, is their most pressing concern[6, 15], and they fear death because they do not want to abandon their children.[91] Spirituality can become an effective coping mechanism for WLH to provide meaning, guidance, support, protection, and inner strength.[92-95]

\section{Study Limitations}

There are several limitations to consider. First, the synthesis relies on the data analyzed from each article that might not reflect the meaning from the raw data. Then, half the studies were conducted in the United States which limits the generalizability of the findings. Despite this limitation, the search included multiple languages due to the multinational team and the database search was extensive. Third, the studies spanned almost three decades, but were defined by the period of HAART. Despite this span of time, there was consistency in the data across the decades. Finally, the search might have excluded studies not published in indexed journals or in different contexts, such as thesis or dissertations. However, the search strategy and the database selection was based on published recommended strategies.

\section{Conclusion}


Reproductive decision-making is a process that WLH encounter with increasing frequency but limited assistance from family, friends, partners, and clinicians. Decisions regarding reproduction cannot be taken for granted or taken autonomously, instead they should be discussed within the context of a supportive health system. This complexity of the situation for WLH requires an integrated approach with comprehensive multidisciplinary counseling to address reproductive decisions and sexual health, including respecting their individual right to become a mother. The institutional, economic, and social barriers that interfere with discussions about reproduction and sexual health need to be to be addressed to prevent unplanned pregnancies, which represent a psychological and socioeconomical burden. Furthermore, the attention of clinicians to these discussions is also vital to guiding policies and practices to improve care for WLH. They need to have the ability to speak with knowledgeable clinicians about the risks and responsibilities for planning a pregnancy in the same way as other women without the infection.

A human caring approach to clinical management focused on education and counseling, respect for personal preferences and individual situations, and person-centered care needs to be implemented for WLH. Similar to women without an HIV diagnosis, clinicians need to engage WLH in reproductive decision-making through family planning and discussing contraception options. In addition, clinicians need to be authentically present when caring for WLH, demonstrating compassion and understanding as they ty to minimize the stigma associated with sexual health. Moreover, empowerment strategies that lead to informed decision-making behaviors need to be implemented in clinical practice. Consequently, education and evidence-based clinical practice guidelines are required to deliver integrated, culturally competent, and comprehensive person-centered care to WLH.

\section{Abbreviations}

LIST

CASP

Critical Appraisal Skills Programme

ENTREQ

Enhancing transparency in reporting the synthesis of qualitative research HAART

Highly active antiretroviral therapy

HIV

Human immunodeficiency virus

$\mathrm{JBI}$

Joanna Briggs Institute

PRISMA

Preferred reporting items for systematic reviews and meta-analyses

PROSPERO

International prospective register of systematic reviews

QRS

Page 23/32 
Qualitative research synthesis

WLH

Women living with HIV

\section{Declarations}

Ethics approval and consent to participate: An ethics approval was not necessary for this project. All the data obtained from a searched of databases. However, all the included studies were research appropriately approved by an ethics committee.

Consent for publication: This consent is not applicable.

Availability of data and material: The data used and/or analyzed during the current study are available from the corresponding author on reasonable request.

Competing interests: The authors declare that they have no competing interests.

Funding: This project was partially supported through a research dissemination grant received from the Universidad Norbert Wiener (VRI-D-2020-07-002-RDG) by Prof. Dr. Patrick A. Palmieri.

Authors' contributions: All authors participated in the final approval of the manuscript submitted for journal review and are accountable for ensuring that questions related to the accuracy and/or integrity of any part of the manuscript are appropriately investigated and resolved. The following authors were involved in the stated phases of the project: Study conception (AHW); study design (AHW, JLM, PAP); data collection (AHW, PAP, JEE, SKC, SAF, LPD, JLM); data analysis (AHW, PAP, JEE, SKC, JLM); data interpretation (AHW, PAP, JEE, SKC, LPD, JLM); drafting the manuscript (AHW, JLM, PAP); table development (LPD, JLM, PAP); substantial revisions to manuscript (AHW, KDC, JLM, PAP), critical revisions to final manuscript (JLM, PAP); and senior scholar guidance (JEE, PAP, SKC).

Acknowledgements: We want to thank Dr. Maria Feijoo-Cid (Universitat Autonoma de Barcelona) for her assistance with the initial review. Also, we recognize Dr. Rosalie Mainous, Dean of the College of Nursing, Texas Woman's University, for continuing to support the Center for Global Nursing, including funding faculty exchanges, and facilitating the global research activities that stimulated this research project.

Corresponding Author's information (optional): PAP is a Fellow of the American Academy of Nursing and a nationally certified researcher (No. P0022630) by the Peruvian National Council of Science, Technology, and Innovation (CONCYTEC). He is the Director, EBHC South America: A JBI Affiliated Group; Vice Chancellor for Research, Universidad Norbert Wiener; Adjunct Professor, College of Graduate Health Studies, A.T. Still University; Adjunct Professor, College of Health Sciences, Walden University; and Adjunct Professor, College of Nursing, Texas Woman's University.

\section{References}


1. 1. Joint United Nations Programme on HIV/AIDS: UNAIDS: Data 2019. Geneva, Switzerland: UNAIDS; 2019.

2. 2. Joint United Nations Programme on HIV/AIDS: Miles to go: Closing gaps, breaking barriers, righting injustices. Geneva, Switzerland: Joint United Nations Programme on HIV/AIDS; 2018.

3. 3. Rodriguez VJ, LaCabe RP, Privette CK, Douglass KM, Peltzer K, Matseke G, Mathebula A, Ramlagan S, Sifunda S, Prado GW, et al: The Achilles' heel of prevention to mother-to-child transmission of HIV: Protocol implementation, uptake, and sustainability. Sahara j 2017, 14:38-52.

4. 4. Kabapy AF, Shatat HZ, Abd El-Wahab EW: Attributes of HIV infection over decades (1982-2018): A systematic review and meta-analysis. Transboundary and Emerging Diseases 2020:Online ahead of print.

5. 5. Teeraananchai S, Kerr SJ, Amin J, Ruxrungtham K, Law MG: Life expectancy of HIV-positive people after starting combination antiretroviral therapy: a meta-analysis. HIV Med 2017, 18:256266.

6. 6. Gomez-Suarez M: Satisfacción de necesidades de anticoncepción en mujeres positivas al VIH: Efecto sobre la eliminación de la transmisión vertical del virus [Meeting contraceptive needs of HIVpositive women: Effect on elimination of vertical transmission of HIV]. Revista Panamericana de Salud Pública 2016, 40:479-484.

7. 7. Harper DC, McGuinness TM, Johnson J: Clinical residency training: Is it essential to the Doctor of Nursing Practice for nurse practitioner preparation? Nursing Outlook 2017, 65:50-57.

8. 8. Leyva-Moral JM, Piscoya-Angeles PN, Edwards JE, Palmieri PA: The experience of pregnancy in women living with HIV: A meta-synthesis of qualitative evidence. Journal of the Association of Nurses in AIDS Care 2017, 28:587-602.

9. 9. Haberl A, Reitter A: How does HIV affect the reproductive choices of women of childbearing age? Antiviral Therapy 2013, 18 35-44.

10. 10. Mazzeo $\mathrm{Cl}$, Flanagan EH, Bobrow EA, Pitter CS, Marlink R: How the global call for elimination of pediatric HIV can support HIV-positive women to achieve their pregnancy intentions. Sexual and Reproductive Health Matters 2012, 20:90-102.

11. 11. McIntyre J: Maternal health and HIV. Sexual and Reproductive Health Matters 2005, 13:129-135.

12. 12. Sowell RL, Phillips KD, Misener TR: HIV-infected women and motivation to add children to their families. Journal of Family Nursing 1999, 5:316-331.

13. 13. Joseph-Davey DL, Pintye J, Baeten JM, Aldrovandi G, Baggaley R, Bekker L-G, Celum C, Chi BH, Coates TJ, Haberer JE, et al: Emerging evidence from a systematic review of safety of preexposure prophylaxis for pregnant and postpartum women: Where are we now and where are we heading? Journal of the International AIDS Society 2020, 23:e25426.

14. 14. Leyva-Moral JM, Palmieri PA, Feijoo-Cid M, Cesario SK, Membrillo-Pillpe NJ, Piscoya-Angeles PN, Goff M, Toledo-Chavarri A, Edwards JE: Reproductive decision-making in women living with human immunodeficiency virus: A systematic review. International Journal of Nursing Studies 2018, 77:207-221. 
15. 15. Wesley Y, Smeltzer SC, Redeker NS, Walker S, Palumbo P, Whipple B: Reproductive decision making in mothers with HIV-1. Health Care for Women International 2000, 21:291-304.

16. 16. Barnes DB, Murphy S: Reproductive decisions for women with HIV: Motherhood's role in envisioning a future. Qualitative Health Research 2009, 19:481-491.

17. 17. Orlando M, Weber S, Martinez R, Cohan D, Seidman D: Safer conception and contraceptive counseling by providers of men living with HIV in San Francisco. Journal of the Association of Nurses in AIDS Care 2017, 28:964-970.

18. 18. European Collaborative Study: Mode of delivery in HIV-infected pregnant women and prevention of mother-to-child transmission: Changing practices in Western Europe. HIV Medicine 2010, 11:368378.

19. 19. Read JS, Newell ML: Efficacy and safety of cesarean delivery for prevention of mother-to-child transmission of HIV-1. Cochrane Database of Systematic Reviews 2005.

20. 20. Aho I, Kaijomaa M, Kivela P, Surcel HM, Sutinen J, Heikinheimo O, with the FSt: Most women living with HIV can deliver vaginally-National data from Finland 1993-2013. PLoS One 2018, 13:e0194370.

21. 21. Bell E, Mthembu P, O'Sullivan S, Moody K: Sexual and reproductive health services and HIV testing: Perspectives and experiences of women and men living with HIV and AIDS. Sexual and Reproductive Health Matters 2007, 15:113-135.

22. 22. Saleem HT, Narasimhan M, Denison JA, Kennedy CE: Achieving pregnancy safely for HIVserodiscordant couples: A social ecological approach. Journal of the International AIDS Society 2017, 20:21331.

23. 23. Fransen R, Guarinieri M: Men living with HIV in serodiscordant relationships who desire a child/children. Journal of the International AIDS Society 2017, 20:21749.

24. 24. Orza L, Bewley S, Crone ET, Mworeko L, Namiba A, Otieno T, Vazquez M, Welbourn A: Ask women living with HIV what's needed to achieve safe pregnancies in serodifferent relationships. Journal of the International AIDS Society 2017, 20:21469.

25. 25. O'Brien N, Greene S, Carter A, Lewis J, Nicholson V, Kwaramba G, Menard B, Kaufman E, Ennabil $\mathrm{N}$, Andersson N, et al: Envisioning women-centered HIV care: Perspectives from women living with HIV in Canada. Womens Health Issues 2017, 27:721-730.

26. 26. Rochat TJ, Bland R, Coovadia H, Stein A, Newell M-L: Towards a family-centered approach to HIV treatment and care for HIV-exposed children, their mothers and their families in poorly resourced settings. Future Virology 2011, 6:687-696.

27. 27. Sina BJ: Pregnancy and the global disease burden. Reproductive Health 2017, 14:170.

28. 28. Sandelowski M, Barroso J, Voils Cl: Using qualitative metasummary to synthesize qualitative and quantitative descriptive findings. Research in Nursing \& Health 2007, 30:99-111.

29. 29. Lockwood C, Munn Z, Porritt K: Qualitative research synthesis: methodological guidance for systematic reviewers utilizing meta-aggregation. International Journal of Evidence-Based Healthcare 2015, 13:179-187. 
30. 30. Nijhof G: "Response Work": Approaching answers to open interviews as readings. Qualitative Inquiry 1997, 3:169-187.

31. 31. Hannes K, Lockwood C: Pragmatism as the philosophical foundation for the Joanna Briggs meta-aggregative approach to qualitative evidence synthesis. Journal of Advanced Nursing 2011, 67:1632-1642.

32. 32. Munn Z, Tufanaru C, Aromataris E: JBI's systematic reviews: Data extraction and synthesis. American Journal of Nursing 2014, 114:49-54.

33. 33. Sandelowski M, Barroso J: Writing the Proposal for a Qualitative Research Methodology Project. Qualitative Health Research 2003, 13:781-820.

34. 34. Milford C, Kriel Y, Njau I, Nkole T, Gichangi P, Cordero JP, Smit JA, Steyn PS: Teamwork in Qualitative Research:Descriptions of a Multicountry Team Approach. International Journal of Qualitative Methods 2017, 16:1609406917727189.

35. 35. Carlsson-Lalloo E, Rusner M, Mellgren A, Berg M: Sexuality and reproduction in HIV-positive women: A meta-synthesis. AIDS Patient Care and STDs 2016, 30:56-69.

36. 36. Huertas-Zurriaga A, Edwards JE, Palmieri PA, Cesario SK, Feijoo-Cid M, Alonso-Fernández S, Pardell-Dominguez L, Leyva-Moral JM: Motherhood decision among women living with HIV. A metasynthesis of qualitative evidence. In PROSPERO: International Prospective Register of Systematic Reviews, vol. 2008; 2018.

37. 37. Moher D, Liberati A, Tetzlaff J, Altman DG: Preferred reporting items for systematic reviews and meta-analyses: The PRISMA statement. BMJ 2009, 339:b2535.

38. 38. Tong A, Flemming K, Mclnnes E, Oliver S, Craig J: Enhancing transparency in reporting the synthesis of qualitative research: ENTREQ. BMC Medical Research Methodology 2012, 12:181.

39. 39. Hickey MD, Odeny TA, Petersen M, Neilands TB, Padian N, Ford N, Matthay Z, Hoos D, Doherty M, Beryer $C$, et al: Specification of implementation interventions to address the cascade of HIV care and treatment in resource-limited settings: a systematic review. Implementation Science 2017, 12:102.

40. 40. Leyva-Moral JM, Loayza-Enriquez BK, Palmieri PA, Guevara-Vasquez GM, Elias-Bravo UE, Edwards JE, Feijoo-Cid M, Davila-Olano LY, Rodriguez-Llanos JR, Leon-Jimenez FE: Adherence to antiretroviral therapy and the associated factors among people living with HIV/AIDS in Northern Peru: a cross-sectional study. AIDS Research and Therapy 2019, 16:22.

41. 41. Mepham S, Bland R, Newell M-L: Prevention of mother-to-child transmission of HIV in resourcerich and -poor settings. BJOG 2011, 118:202-218.

42. 42. Tudor Car L, van-Velthoven M, Brusamento S, Elmoniry H, Car J, Majeed A, Atun R: Integrating prevention of mother-to-child HIV transmission (PMTCT) programmes with other health services for preventing HIV infection and improving HIV outcomes in developing countries. Cochrane Database of Systematic Reviews 2011.

43. 43. Stansfield C, Brunton G, Rees R: Search wide, dig deep: Literature searching for qualitative research. An analysis of the publication formats and information sources used for four systematic reviews in public health. Research Synthesis Methods 2014, 5:142-151. 
44. 44. Flemming $\mathrm{K}$, Briggs $\mathrm{M}$ : Electronic searching to locate qualitative research: evaluation of three strategies. Journal of Advanced Nursing 2007, 57:95-100.

45. 45. Wilczynski NL, Marks S, Haynes RB: Search strategies for identifying qualitative studies in CINAHL. Qualitative Health Research 2007, 17:705-710.

46. 46. Bramer WM, Giustini D, Kleijnen J, Franco OH: Searching Embase and MEDLINE by using only major descriptors or title and abstract fields: a prospective exploratory study. Systematic Reviews 2018, 7:200.

47. 47. Wong SS, Wilczynski NL, Haynes RB: Developing optimal search strategies for detecting clinically relevant qualitative studies in MEDLINE. Studies in Health Technology and Informatics 2004, 107:311-316.

48. 48. McKibbon KA, Wilczynski NL, Haynes RB: Developing optimal search strategies for retrieving qualitative studies in PsycINFO. Evaluation \& the Health Professions 2006, 29:440-454.

49. 49. Shaw RL, Booth A, Sutton AJ, Miller T, Smith JA, Young B, Jones DR, Dixon-Woods M: Finding qualitative research: An evaluation of search strategies. BMC Medical Research Methodology 2004, 4:5.

50. 50. Porritt K, Gomersall J, Lockwood C: JBI's Systematic Reviews: Study Selection and Critical Appraisal. American Journal of Nursing 2014, 114:47-52.

51. 51. Atkins $S$, Lewin S, Smith $H$, Engel $M$, Fretheim A, Volmink J: Conducting a meta-ethnography of qualitative literature: Lessons learnt. BMC Medical Research Methodology 2008, 8:21.

52. 52. Rojon C, Saunders MNK: Formulating a convincing rationale for a research study. Coaching 2012, 5:55-61.

53. 53. Toye F, Seers K, Allcock N, Briggs M, Carr E, Barker K: Meta-ethnography 25 years on: Challenges and insights for synthesising a large number of qualitative studies. BMC Medical Research Methodology 2014, 14:80.

54. 54. Finfgeld-Connett D, Johnson ED: Literature search strategies for conducting knowledge-building and theory-generating qualitative systematic reviews. Journal of Advanced Nursing 2013, 69:194204.

55. 55. Critical Appraisal Skills Programme: CASP qualitative research checklist. Oxford, England: CASP UK; 2016.

56. 56. Majid U, Vanstone M: Appraising qualitative research for evidence syntheses: A compendium of quality appraisal tools. Qualitative Health Research 2018, 28:2115-2131.

57. 57. Dixon-Woods $M$, Sutton A, Shaw R: Appraising qualitative research for inclusion in systematic reviews: A quantitative and qualitative comparison of three methods. Journal of Health Services Research \& Policy 2007, 12:42-47.

58. 58. Ludvigsen MS, Hall EOC, Meyer G, Fegran L, Aagaard H, Uhrenfeldt L: Using Sandelowski and Barroso's meta-synthesis method in advancing qualitative evidence. Qualitative Health Research 2016, 26:320-329. 
59. 59. Sandelowski M, Barroso J: Handbook for synthesizing qualitative research. 1 edn. New York, NY: Springer Publishing Company; 2006.

60. 60. Barroso J, Sandelowski M: Sample reporting in qualitative studies of women with HIV infection. Field Methods 2003, 15:386-404.

61. 61. Fereday J, Muir-Cochrane E: Demonstrating rigor using thematic analysis: A hybrid approach of inductive and deductive coding and theme development. International Journal of Qualitative Methods 2006, 5:80-92.

62. 62. Braun V, Clarke V: Using thematic analysis in psychology. Qualitative Research in Psychology 2006, 3:77-101.

63. 63. King N: Using templates in the thematic analysis of text. In Essential Guide to Qualitative Methods in Organizational Research. Volume New York, NY. Edited by Cassell C, Symon G. London: SAGE Publications; 2004: 257-270

64. 64. Morse JM: Critical analysis of strategies for determining rigor in qualitative inquiry. Qualitative Health Research 2015, 25:1212-1222.

65. 65. Morse JM, Barrett M, Mayan M, Olson K, Spiers J: Verification strategies for establishing reliability and validity in qualitative research. International Journal of Qualitative Methods 2002, $1: 13-22$.

66. 66. Shenton AK: Strategies for ensuring trustworthiness in qualitative research projects. Journal: Education for Information 2004, 22:63-75.

67. 67. Walsh D, Downe S: Meta-synthesis method for qualitative research: A literature review. Journal of Advanced Nursing 2005, 50:204-211.

68. 68. Siegel K, Schrimshaw EW, Lekas HM: Diminished sexual activity, interest, and feelings of attractiveness among HIV-infected women in two eras of the AIDS epidemic. Archives of Sexual Behavior 2006, 35:437-449.

69. 69. Walulu RN, Gill SL: Role of spirituality in HIV-infected mothers. Issues in Mental Health Nursing 2011, 32:382-384.

70. 70. Kelly C, Lohan M, Alderdice F, Spence D: Negotiation of risk in sexual relationships and reproductive decision-making amongst HIV sero-different couples. Culture, Health \& Sexuality 2011, 13:815-827.

71. 71. Kirshenbaum SB, Hirky AE, Correale J, Goldstein RB, Johnson MO, Rotheram-Borus MJ, Ehrhardt AA: "Throwing the dice": Pregnancy decision-making among HIV-positive women in four U.S. cities. Perspectives on Sexual and Reproductive Health 2004, 36:106-113.

72. 72. Sanders LB: Women's voices: the lived experience of pregnancy and motherhood after diagnosis with HIV. Journal of the Association of Nurses in AIDS Care 2008, 19:47-57.

73. 73. Jean J, Coll A, Monda M, Potter J, Jones D: Perspectives on safer conception practices and preconception counseling among women living with HIV. Health Care for Women International 2016, 37:1096-1118. 
74. 74. Campero L, Kendall T, Caballero M, Mena AL, Herrera C: El ejercicio de los derechos sexuales y reproductivos: Un estudio cualitativo de personas heterosexuales con VIH en México [Exercising sexual and reproductive rights: a qualitative study of heterosexual people with HIV in Mexico]. Salud Pública de México 2010, 52:65-69.

75. 75. Kelly $C$, Reid E, Lohan M, Alderdice F, Spence $D$ : Creating an eLearning resource to improve knowledge and understanding of pregnancy in the context of HIV infection. International Journal of Environmental Research and Public Health 2014, 11:10504-10517.

76. 76. Giles ML, Hellard ME, Lewin SR, O'Brien ML: The "work" of women when considering and using interventions to reduce mother-to-child transmission (MTCT) of HIV. AIDS Care 2009, 21:1230-1237.

77. 77. Barnes DB: "I always wanted to see my babies grow up": Motherhood experiences for women living longer than expected with HIV/AIDS. In Women, motherhood and living with HIV/AIDS: A crosscultural perspective. Edited by Liamputtong P. Dordrecht: Springer Netherlands; 2013: 113-127

78. 78. Cuca YP, Rose CD: Social stigma and childbearing for women living with HIV/AIDS. Qualitative Health Research 2016, 26:1508-1518.

79. 79. Keegan A, Lambert S, Petrak J: Sex and relationships for HIV-positive women since HAART: A qualitative study. AIDS Patient Care and STDs 2005, 19:645-654.

80. 80. Sanders LB: Sexual behaviors and practices of women living with HIV in relation to pregnancy. Journal of the Association of Nurses in AIDS Care 2009, 20:62-68.

81. 81. Hult JR, Wrubel J, Branstrom R, Acree M, Moskowitz JT: Disclosure and nondisclosure among people newly diagnosed with HIV: An analysis from a stress and coping perspective. AIDS Patient Care and STDs 2012, 26:181-190.

82. 82. Land H, Linsk N: HIV stigma and discrimination: Enduring issues. Journal of HIV/AIDS \& Social Services 2013, 12:3-8.

83. 83. Kylmä J, Vehviläinen-Julkunen $\mathrm{K}$, Lähdevirta J: Hope, despair and hopelessness in living with HIV/AIDS: A grounded theory study. Journal of Advanced Nursing 2001, 33:764-775.

84. 84. Herek G, Saha S, Burack J: Stigma and psychological distress in people with HIV/AIDS. Basic and Applied Social Psychology 2013, 35:41-54.

85. 85. Friedman E, Orlando MS, Anderson J, Coleman JS: "Everything I needed from her was everything she gave back to me:" An evaluation of preconception counseling for U.S. HIV-serodiscordant couples desiring pregnancy. Womens Health Issues 2016, 26:351-356.

86. 86. Wilson TE, Jean-Louis G, Schwartz R, Golub ET, Cohen MH, Maki P, Greenblatt R, Massad LS, Robison E, Goparaju L, Lindau S: HIV infection and women's sexual functioning. Journal of Acquired Immune Deficiency Syndromes 2010, 54:360-367.

87. 87. Lassi ZS, Imam AM, Dean SV, Bhutta ZA: Preconception care: preventing and treating infections. Reproductive Health 2014, 11:S4.

88. 88. Brashers DE, Neidig JL, Goldsmith DJ: Social support and the management of uncertainty for people living with HIV or AIDS. Health Communication 2004, 16:305-331. 
89. 89. Mahajan AP, Sayles JN, Patel VA, Remien RH, Sawires SR, Ortiz DJ, Szekeres G, Coates TJ: Stigma in the HIV/AIDS epidemic: A review of the literature and recommendations for the way forward. AIDS 2008, 22 S67-S79.

90. 90. Eliott JA (Ed.). Interdisciplinary perspectives on hope. Hauppauge, NY: Nova Science Publishers; 2005.

91. 91. Matão MEL, Miranda DBd, Freitas MIdF: Entre el deseo, el derecho y el miedo a ser madre tras seropositividad del HIV [Between desire, duty and fear of being a mother after HIV seropositivity]. Enfermería Global 2014, 13.

92. 92. Anderson J, Doyal L: Women from Africa living with HIV in London: A descriptive study. AIDS Care 2004, 16:95-105.

93. 93. Jesse DE, Schoneboom C, Blanchard A: The effect of faith or spirituality in pregnancy: A content analysis. Journal of Holistic Nursing 2007, 25:151-158; discussion 159.

94. 94. Medved Kendrick $\mathrm{H}$ : Are religion and spirituality barriers or facilitators to treatment for HIV: A systematic review of the literature. AIDS Care 2017, 29:1-13.

95. 95. Pinho CM, Damaso BF, Gomes ET, Trajano MF, Andrade MS, Valenca MP: Religious and spiritual coping in people living with HIV/AIDS. Revista Brasileira de Enfermagem 2017, 70:392-399.

\section{Figures}
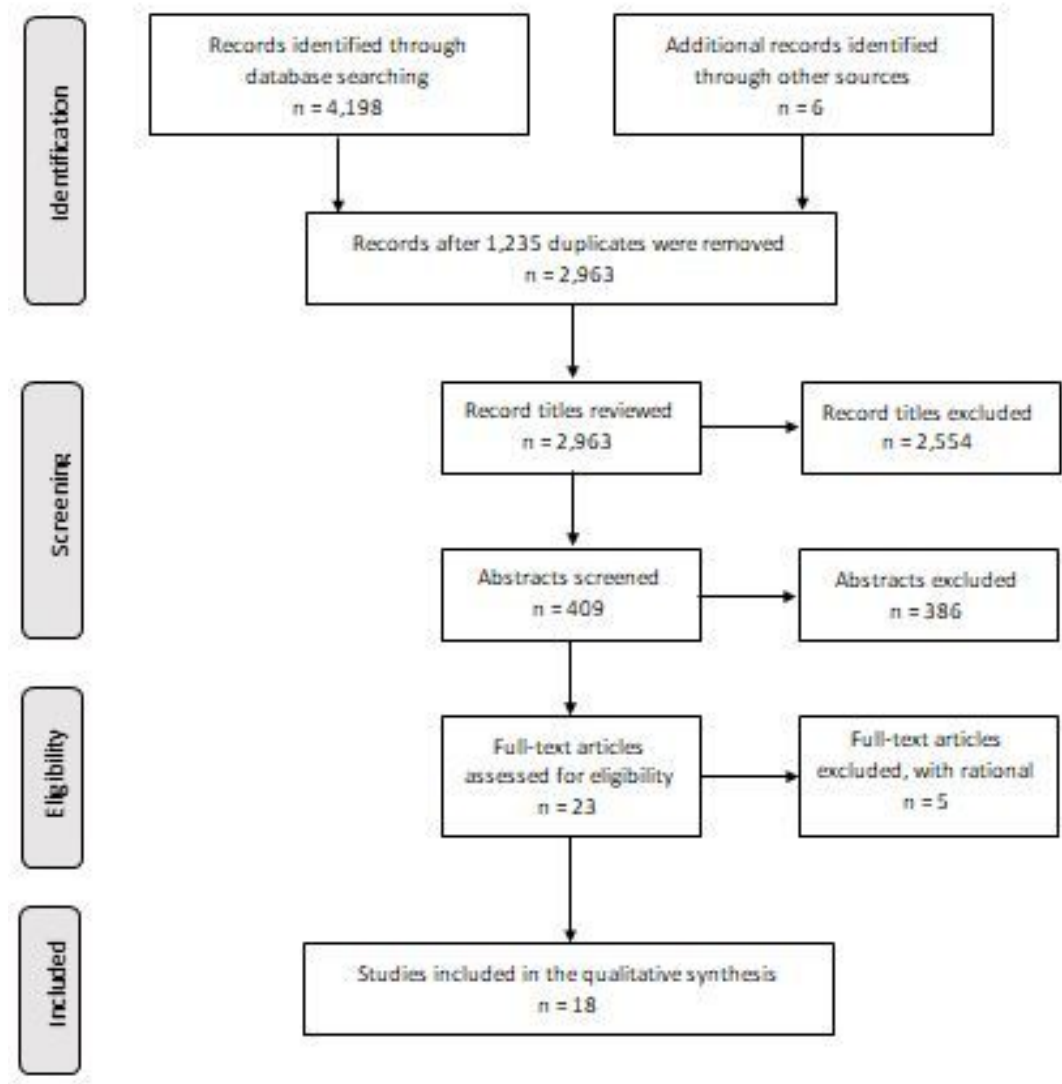

Figure 1 
PRIMSA Diagram

\section{Supplementary Files}

This is a list of supplementary files associated with this preprint. Click to download.

- RHCOVERLETTER2020.06.18FINAL.docx 